\title{
The Quality of Work Done in Secondary Schools
}

\author{
GEORGE E, CARROTHERS \\ University of Michigan, Ann Arbor, Michigan
}

The quality of work done in secondary schools is probably better in some respects than it has been at any previous time. That it is not, however, meeting fully the expectations of many groups of adults is clearly evident from the number of criticisms one hears almost daily (1) from employers who claim that secondary-school graduates can neither read nor write acceptably nor can they perform with accuracy even simple arithmetical computations, (2) from college professors who insist that freshmen of today are not able to handle as difficult courses as freshmen of a generation ago, and (3) from parents who complain of numerous ways in which schools fall short of what ought to be expected of them. Some of the criticisms can be discounted, yet enough of them are founded on fact, to warrant and to suggest careful study on the part of persons interested in secondary education.

\section{INCREASED TEACHING LOAD}

In the first place, society is expecting far more of teachers today than ever before. Much of the general education of children and youths was formerly cared for by the home, the church, and the community. Today this is changed. Clotning is made in factories, bread is baked at the bakery, other foods come in cans already cooked, the chores which formerly occupied the time and attention of boys have largely disappeared, and with these under normal conditions, the opportunity for work experience. Schools are now expected to teach not only the formal school subjects but also to act as parents, ministers, personal adviser, and community leader. Enrollments have increased several hundred per cent in the past generation, classes have become crowded, extracurriculum activities have been added to the regular teaching load, and other duties are expected. The job of teaching today is much more arduous than during any previous time. Naturally, all of this work cannot be performed on the same high level which was attained when a teacher was responsible only for the academic performance of the boys and girls in his classes. Formerly also a high degree of selection was practiced in secondary education, pupils were eliminated who did not do good work and those who remained did work of a highly acceptable quality.

After all allowances have been made, it is clear that teachers are not securing from large numbers of pupils that quality of work which they have a right to expect. Pupils are not developing the habits, skills, and attitudes of which they are capable, so that later they are greatly handicapped when called on to meet life situations. One dare not do less than his best today or he is weakened for tomorrow. Pupils, permitted to do less than their best day after day, find themselves handicapped at the end of their four years of high school. 
It may be that no one in particular is to blame; yet the unfavorable situation exists, and some very fine boys and girls are being shortchanged. Some day they will become cognizant of their educational loss and will severely condemn their teachers unless we who can do something about it, bestir ourselves at once. We are their teachers, and the teachers of their teachers. These pupils have a right to expect us to hold them to good performance.

SIX PHASES OF THE PROBLEM NEED CONSIDERATION

Several phases of this question have been examined, and are hereafter explained in some detail. In this examination it must be understood that not all of the fault lies with secondary-school teachers. Parents, the public in general, faculties of liberal arts colleges, and other teacher-training institutions, as well as easy-going administrators, must accept their fair share of the responsibility for the poor quality of work which is accomplished. Six phases of the problem need serious, sympathetic consideration: (1) the Santa Claus notion among adults which is now settling down upon teen-age youth, (2) the recommending to teacher-training institutions of "good" pupils who would not be recommended to colleges of engineering or to liberal arts colleges, (3) the less exacting quality of college work sometimes expected of students who are planning to become teachers, (4) the overemphasis during the past decade or two on teaching instead of pupil learning, (5) the "constant tutorial presence of the teacher" idea, and (6) the "letdown" in the senior year of the secondary school. Each of these will be treated briefly.

\section{The Santa Claus Notion}

Time was when pupils gladly assisted teachers in doing many of the extra duties in the laboratories, libraries, gymnasiums, and other teaching rooms. That has largely disappeared during the depression and government funds to pay for these extra activities. Many a laboratory table or room is now being left in an untidy, sloppy condition by pupils who know that someone will clean up after them. This has led to the feeling that teachers ought to help the pupils more with their lessons, that equipment ought to be arranged by the teacher, that carefully prepared, so-called workbooks should be furnished, with only a small space here and there to be filled in by a word or two, and that the teacher or older pupils ought to furnish the word if the pupil doesn't guess it at once. It is feared that many a fine, capable boy or girl is missing the development of that innate self-reliance and self-respect which long has been considered a prized possession of American youth, and that teachers, patrons, and public will have to join in a concerted effort if uniform superior work is again to be the order of the day in the secondary school.

\section{Ability of Students in Normal Schools}

The second problem is of equal importance. Studies made during the past decade or two show rather clearly that students entering normal schools, 
teachers colleges, and other teacher-training institutions have not ranked as high on intelligence tests as freshman students entering liberal arts colleges. This fact has been known to principals of secondary schools, and they have made use of it when recommending students to college. It is likewise known that in many teacher-training institutions curriculums have been, and have had to be, attenuated. Also, in some liberal arts colleges a less exacting program of work is expected of those students who indicate a desire to teach, somewhat after the manner of favoring persons preparing to do missionary work.

Other reasons might be mentioned, but whatever the influences which have brought about this not-to-be desired situation, it is with us. Collegeadmission officers know that some school administrators refuse rather def-initely to recommend secondary-school graduates to liberal arts and engineering colleges although they will recommend them to teachers colleges. As a result, four years later, the average ability of prospective teachers is not as high as it should be. In turn, teaching is now well done, the pupils suffer, and a vicious circle is established.

\section{Quality of Work Expected of Prospective Teachers}

The third problem is concerned with the field of teacher training, which has developed so rapidly during the past generation that it has been practically impossible to organize all of the varied education courses offered on a carefully planned, progressively more difficult basis. As a result there has been much overlapping of subject matter, great difficulty in holding students to first-class performance, and rather inexpert and inefficient examining and evaluating of work accomplished. This in turn has resulted in many instances in the awarding of high marks to teachers and prospective teachers for average or even inferior work. This has carried over to the secondary school and resulted in a continuous moving along of pupils from grade to grade or course to course whether they come through with efficient performance or not.

Pupils and teachers alike seem surprised when one of the popular highschool graduates is informed by his first "boss" that he cannot write even a fair business letter, that his penmanship is almost illegible, that he missspells even simple words, and that many of his arithmetical calculations are incorrect. Surprise also comes when these pampered pupils attempt to do work in a first-class college. And still greater surprise ought to be manifest when these "poor" students seek to enter teacher-training institutions.

To hold pupils to first-class performance is, of course, more difficult than to write these words. Also, it is realized that thousands of secondary-school graduates are so well trained that they experience but little difficulty in adjusting themselves to positions in business and industry or to college life; yet it is also clearly known that there are other thousands of youth in both 
the secondary schools and normal schools who are being permitted to obtain an altogether false notion as to their abilities and accomplishments.

\section{Emphasis on Teaching Instead of Learning}

The fourth problem, overemphasis on teaching, is in part also a result of unusual attention given to the education or professional training of teachers. There is probably no question in the mind of any widely educated person concerning the necessity for better-trained professional workers in a modern civilized society. Training for law, medicine, the ministry, teaching, and for every other vocation entitled to be called a profession, has been greatly increased during the past generation, and the most rapid increase has probably been in teaching. Teachers are cognizant of the difficulties of their task. Teaching techniques are being studied. Better teaching is being demanded by administrators. But the emphasis is too great on teaching. Greater emphasis ought to be placed on pupil learning.

Far-seeing, intelligent, right-minded parents who understand the laws of human growth and development are able unobtrusively to plan programs for their children, to give them certain tasks to perform, together with a minimum of suggestion for their performance, and then to get out of their way. In the doing of the tasks by themselves, children grow. Properly educated teachers also work intelligently with pupils in the planning of educational programs and in the assignment of topics or lessons for study. Teaching acts are reduced to a minimum and learning is magnified. The teacher studies ways and means to become more skillful at suggesting problems and arranging stimulating, interesting situations, more expert in collecting materials and useful equipment, and more adept at proposing questions which may lead to right solutions without directly divulging the answers.

In recent years we have so emphasized and talked about teaching that many of the teachers who have large accumulations of semester hours in summer school and other professional education courses have become overly teaching conscious. They feel that they must supervise and talk to the pupils all the time. It convinces pupils that the teacher is greatly interested in them, and it makes a good impresson if the superintendent or a patron happens to come to the class. On the other hand, larger quantities and better quality of pupil learning may take place if a teacher can at times content himself with becoming a good stage-setter, if he can withdraw from the center of the picture and permit pupils to solve their own problems. In many schools today there is great need for a shift of emphasis from the much-talking, teacher-dominated class recitation to a teacher-planned, pupilexecuted, learning situation.

\section{Constant Tutorial Presence of the Teacher}

Secondary schools in this country are in need of a new conception of the process of intellectual growth, or possibly a return to the good old laws of learning formerly observed in practice before educational psychology had 
been "studied" so intensively, and prior to the advent of the ultramodern progressives in education. Fifteen years ago $\mathrm{H}$. C. Morrison stated that the secondary school is the region in which the pupil is capable of study but is incapable of systematic intellectual growth except under the constant tutorial presence of the teacher. ${ }^{2}$

It now appears that many secondary-school teachers have been taking Professor Morrison literally and seriously. Carried to the extreme in many secondary schools, this idea of "constant tutorial presence" is resulting in retarded development of initiative and stunted growth of independent selfhelp on the part of pupils. In fact, so helpless, incompetent, and lacking in initiative and ingenuity are many of the otherwise potentially capable boys and girls in secondary schools that they are developing confirmed habits of running to the teacher, to the principal, to older pupils, or to almost anyone else available the moment a slight difficulty confronts them instead of shutting out the outside disturbances, buckling their belts a hole tighter, scratching their own heads, and trying individually to work out the answers for themselves.

The permitting of pupils to take five or six subjects in the secondary school, noted in different places in a recently issued report, ${ }^{2}$ reveals another phase of this situation, one which renders practically impossible the doing of first-class work by either pupils or their teachers. This practice definitely increases the burden placed on teachers and seriously interferes with good learning. Instead of registering pupils in four subjects and then expecting them to use the free periods for individual, independent work, the tendency seems to be to permit pupils to enroll in enough subjects and courses so they will be in continuous recitation and under direct teacher supervision throughout the day. This adds greatly to the teacher load and suggests the idea that the teacher is to do much of the work for the pupil. On one transcript recently sent from a secondary school to the admissions officer in a college, it was noted that the incoming freshman had taken seven subjects the last year in secondary school, one in each sixty-minute period during a six-period day, and still another from a tutor outside school hours. This young man had had so much done for him in the secondary school, and so seldom had been permitted to run on his own power that it is small wonder he had great difficulty as a college freshman. In college he was not able to ask for help in every little diffculty or to seek favors from those who knew him; he was but one among many, and all strangers "on their own." Before the first semester ended he found the college world a "cold world," he withdrew and went back to his home town.

1Morrison, Henry C. The Practice of Teuching in the Secondary School, Chicago: The University of Chicago Press, 1926. p. 7 .

${ }^{2}$ Carrothers, George E. Annual Report of the Bureat of Co-operation with Educational Institutions. University of Michigan, 1940. 


\section{The "Let-down" in the Senior Year}

The senior year in many a secondary sehool is a particularly critical period for both pupils and teachers. Prescribed college entrance units in most instances have been reduced to ten, and these have often been completed in the first three years of the secondary school. The senior class is composed of older pupils who frequently assume that they should be assigned less exacting tasks. The senior play, class night, skip day, class annual, senior dances and parties, and many other extra activities crowd for time and attention, and not infrequently puppy-love affairs develop which upset the equilibrium of not only two, but sometimes several individuals. From onehalf to nine-tenths of the seniors are not planning to go to college, and even those who are contemplating further education feel secure in the knowledge that college entrance requirements have been met and that college is still a year away. Many new interests call these older boys and girls to additional activities in the home and community, and yet there is only so much energy available and only twenty-four hours in the day. Teachers have become quite well acquainted with the pupils during the secondary-school years, and they are anxious to stand well with them as departing seniors, now young men and women; hence easing up on some of the requirements. Commencement arrives and seemingly all are happy.

The day of reckoning comes when even simple educational tests on penmanship, spelling, English, and arithmetic are administered by business firms to prospective employees, and more definitely later when the "hasbeen" senior attempts to do consistently good work for his employer or is in the Army, Navy, or Marines. The secondary-school graduate as a freshman in college frequently finds difficulty in doing acceptable work in English, science, mathematics, and other rather simple subjects. When he awakens to the actual situation, he begins almost immediately to blame the secondary school for not holding him to first-class work and good study habits during his senior year. If secondary-school teachers could listen in on some of the unorganized evening sessions in the freshman dormitory about mid-semester, they would be much better able to hold oncoming seniors to good consistent performance.

Another, and perhaps a more serious phase of this senior-year letdown is occasioned by the attempt, particularly in the smaller community, to graduate every pupil who has remained in school throughout the four years. People in the United States have long been committed to the idea that every youth who desires an education is entitled to it. Enrollments in secondary schools in this country have reached nearly seven millions. Accompanying this idea of education for all youth, there seems to be emerging the idea that everyone who desires it is entitled to a secondary-school diploma. Pupils who have given a major portion of their interest and attention to 
athletics, to band and orchestra, to shop and other activities as well as those who have not done much of anything except attend school, often find themselves continuing with the seniors in their numerous class activities even though they have accumulated only eight to ten units of credit during the previous three years in school. But they want to be graduated. The desire for the diploma seems to increase with its nearness in time and distance in achievement.

The pupil who is short in required units sees the superintendent and requests permission to take five, six, or seven and occasionally eight subjects during the last year, in order that he may be graduated with his class. The administrator knows what the answer should be but he yields, and grants the boy, or girl, permission to try the extra subjects. The theory seems to be that the pupil having been unable to carry successfully more than two or three subjects during each of the first years of high school has laid a foundation which will enable him to carry successfully twice the amount.

Teachers are "on the spot." They do not want to cause trouble, so they arrange their work to meet the level of ability of the weaker pupils. Another senior let-down comes, and all pupils are the losers. The situation is disastrous to the welfare of both "good" and "poor" pupils. Nor is the writer making any boastful comments as to what he would do if he were one of the teachers trying at the last moment to secure a diploma for a pupil who has not earned it. The writer cannot soon forget a long delayed commencement program one evening in a certain Ohio town a few years ago. Finally, on investigation, it was learned that the secretary of the board of education was having a "conference" with a teacher who had given his son a failing mark in some make-up work. The end of the conference came and the commencement exercises started when the secretary told the teacher that he would be "fired" immediately if the boy was not graduated.

The secondary school of today is definitely making an attempt to meet the educational needs of all boys and girls between the ages of fourteen and eightecn or nineteen. No other country has witnessed the expansion of educational facilities and the rapid increase in secondary-school enrollments which this country has experienced. But in the hurried attempt to plan curriculums suitable for all, to train teachers rapidly enough to "man the guns" at all points, these schools seemingly have tried to "be all things to all men," with the result that large numbers of capable pupils have not been held to that kind and quality of performance which would mean educational development for them. These capable pupils have been permitted to fall into slovenly, careless, indolent ways which, developed into habits, have later proved to be serious handicaps when life situations have had to be faced. The solution of the problem will come when teachers and administrators plan programs suited to the abilities of different groups. 